\title{
ANALISIS FAKTOR RISIKO DAN LUARAN DARI PENGGUNAAN TERAPI ANTIBIOTIK EMPIRIK JANGKA PANJANG PADA BAYI DENGAN BERAT LAHIR SANGAT RENDAH DALAM KONDISI SEPSIS
}

\author{
Muhammad Reza* ${ }^{\star 凶}$, Mahendra Tri Arif Sampurna* Kartika Darma Handayani, Dina Angelika*, \\ Martono Tri Utomo*, Risa Etika*, Agus Harianto*
}

\begin{abstract}
Abstrak
Terapi antibiotik berkepanjangan pada neonatus menyebabkan beberapa konsekuensi negatif meliputi resistensi antibiotik, sepsis awitan lambat, enterocolitis nekrotikan (EKN), lama rawat lebih panjang, dan peningkatan mortalitas. Semua faktor tersebut mempengaruhi efisiensi biaya pelayanan rumah sakit di era Jaminan Kesehatan Nasional. Penelitian ini bertujuan untuk menganalisis faktor risiko dan luaran dari terapi antibiotik berkepanjangan pada bayi berat lahir sangat rendah (BBLSR) dengan sepsis. Desain penelitian adalah studi retrospektif pada BBLSR dengan sepsis di Neonatal Intensive Care Unit (NICU), RSUD Dr. Soetomo, Surabaya sejak Januari-Desember 2017 dilakukan dengan membandingkan luaran antara kelompok I yang mendapat terapi antibiotik empirik kurang dari sama dengan 2 minggu dengan kelompok II yang mendapat terapi antibiotik empirik lebih dari 2 minggu empirik. Dari 87 bayi yang termasuk ke dalam studi, 37 bayi termasuk dalam kelompok I dan 50 bayi dalam kelompok II. Rerata durasi terapi antibiotik pada kelompok I dan kelompok II adalah 9,2 $\pm 2,5$ dan 17,9 $\pm 3,2$ hari, dengan lama rawat inap $19,7 \pm 8,5$ dan $27,2 \pm 13,1$ hari. Analisis faktor risiko menunjukkan bahwa BBLSR terutama 1000 gram ( $p<$ $0,001)$, ventilasi mekanik invasif $(p<0,001)$, ventilasi mekanik non-invasif $(p<0,001)$, korioamnionitis $(p=$ $0,003)$, penyakit maternal $(p=0,004)$, kehamilan multipel $(p=0,03)$ merupakan faktor risiko mendapatkan terapi antibiotik empirik berkepanjangan. Luaran dari terapi antibiotik empirik berkepanjangan adalah 41 $(47 \%)$ bayi mengalami sepsis awitan lambat, 15 (17\%) bayi dengan EKN, dan 11 (12\%) bayi meninggal. Mortalitas bayi dengan sepsis awitan lambat $(p<0,001)$ dan EKN $(p=0,02)$ lebih tinggi pada kelompok II dibandingkan kelompok I. Kesimpulannya, terapi antibiotik empirik berkepanjangan meningkatkan angka kejadian sepsis awitan lambat, enterocolitis nekrotikan, lama rawat, dan mortalitas BBLSR di NICU yang berdampak meningkatkan biaya pelayanan rumah sakit.
\end{abstract}

Kata kunci: antibiotik, neonatus, sepsis.

\section{ANALYSIS OF THE RISK FACTORS AND THE OUTCOME OF PROLONGED ANTIBIOTIC THERAPY IN VERY LOW BIRTH WEIGHT INFANT WITH SEPSIS}

\begin{abstract}
Prolonged antibiotic therapy in neonate results in several adverse consequences including widespread antibiotic resistance, late-onset sepsis, necrotizing enterocolitis (NEC), prolonged hospital course and increase in mortality rates. All factors affect the efficacy of hospitality costs in the National Health Coverage era. This research was to assess the risk factors and the outcome of prolonged antibiotic therapy in very low birth weight (VLBW) infants. This was a retrospective study in VLBW infants admitted to Neonatal Intensive Care Unit (NICU) Dr. Soetomo Teaching Hospital, Surabaya from January-December 2017. Compare the outcome between group I ( $\leq 2$ weeks) and group II (>2 weeks) in using antibiotics therapy. The results showed that out of 87 infants included in the study, 37 were in group I, and 50 in group II. Average duration of antibiotic therapy in group I and group II was $9.2 \pm 2.5$ and $17.9 \pm 3.2$ days with hospital stay was $19.7 \pm 8.5$ and $27.2 \pm 13.1$ days. Analysis revealed following risk factors as significant for prolonged empiric antibiotic therapy VLBW especially 1000 grams, $(p<0.001)$, mechanical invasive ventilation $(p<0.001)$, mechanical non-invasive ventilation $(p<0.001)$, chorioamnionitis $(p=0.003)$, maternal illness $(p=0.004)$, multiple pregnancy $(p=0.03)$. There were $41(47 \%)$ infants developed late-onset sepsis, $15(17 \%)$ with NEC, 11 $(12 \%)$ died. Infant mortality with late-onset sepsis $(p<0.01)$ and NEC $(p=0.02)$ was higher in group II. To conclude, prolonged empiric antibiotic therapy increasing rates of late-onset sepsis, NEC, prolonged hospitality course and VLBW infant mortality in NICU which effected increase the hospitality cost.
\end{abstract}

Keywords: antibiotic, neonate, sepsis.

* Departemen IImu Kesehatan Anak, Fakultas Kedokteran Universitas Airlangga-RSUD Dr.Soetomo,

Surabaya

凶E-mail: reza.paed@gmail.com 


\section{Pendahuluan}

Antibiotik merupakan medikasi yang paling umum diresepkan di unit neonatal intensive care unit (NICU), terutama pada neonatus yang terlahir dengan risiko infeksi yang ditunjang dengan tampilan klinis sepsis serta pemeriksaan penunjang yang mendukung ke arah pertanda sepsis. ${ }^{1}$ Namun demikian antibiotik tidak hanya membunuh mikroorganisme, antibiotik juga berpotensi untuk menyebabkan efek samping yang tidak diinginkan terhadap manusia, terutama bagi kelompok neonatus. ${ }^{3}$

Salah satu tantangan yang dihadapi oleh neonatologist di era Jaminan Kesehatan Nasional (JKN) adalah melakukan pelayanan dalam perawatan bayi berat lahir sangat rendah (BBLSR) dengan sepsis, yang membutuhkan terapi antibiotik dengan waktu yang berkepanjangan. Agar rumah sakit tidak merugi serta keselamatan pasien tetap menjadi yang utama, semua biaya yang diperlukan wajib disesuaikan dengan besaran tarif berdasar diagnosis dari asuransi kesehatan pemerintah yaitu KIS (Kartu Indonesia Sehat), KIS merupakan produk dari Badan Penyelenggara Jaminan Sosial (BPJS) sebagai badan yang dipercaya oleh pemerintah untuk mengelola program Jaminan Kesehatan $\mathrm{Na}$ sional (JKN) ini agar merata kepada seluruh masyarakat demi menggapai target universal health coverage yang telah dicanangkan pemerintah.

Banyak studi telah menunjukkan bahwa $65 \%$ neonatus di NICU diberikan antibiotik parenteral untuk lebih dari 7 hari walaupun hasil kultur negatif. 4,5 Antibiotik tetap diberikan apabila terdapat indikasi adanya kecurigaan infeksi bakteri walaupun hasil kultur darah tidak ditemukan pertumbuhan bakteri. Kultur darah negatif belum dapat menyingkirkan terjadinya sepsis. Oleh karena itu, indikator sepsis seperti IT ratio, CRP, procalcitonin dibutuhkan sebagai penunjang diagnosis sepsis. Kultur darah negatif dapat terjadi karena pasien telah mendapatkan terapi antibiotik sebelum diambil sampel untuk kultur darah. Praktek ini menyebabkan peningkatan dari resistensi antibiotik, kejadian sepsis awitan lambat, infeksi jamur, outbreak berbagai infeksi lainnya di NICU, lama rawat yang semakin panjang, peningkatan biaya, dan akhirnya mortalitas dari bayi. 3,6,7 Di sisi lain, tidak memberikan antibiotik pada neonatus dengan kondisi sepsis, dapat pula menyebabkan peningkatan angka mortalitas hingga $20 \%$ pada BBLSR. ${ }^{8}$ Faktanya, angka mortalitas pada neonatus dengan infeksi sistemik mencapai 3 kali lipat lebih tinggi dibandingkan dengan yang tidak mengalami infeksi. ${ }^{9}$

Walaupun semua ahli setuju mengenai perlunya memulai antibiotik pada neonatus kondisi sepsis dengan kultur yang positif, namun terdapat pandangan dan praktek yang berbeda pada masing-masing pusat pelayanan neonatus mengenai inisiasi serta durasi dari antibiotik pada neonatus yang masih dicurigai sepsis atau klinis sepsis (kultur negatif). Perbedaan ini mungkin sebagian disebabkan karena adanya berbagai faktor risiko, seperti preeklampsia, korioamnionitis, asfiksia, jenis kelamin bayi, berat badan lahir sangat rendah, usia persalinan muda, pemberian makan bayi, kebutuhan inotropik, invasive ventilation ataupun non-invasif ventilation (NIV), penggunaan surfaktan, dan lainlainnya. ${ }^{3}$ Studi ini dilakukan untuk menilai faktor risiko dari terapi antibiotik empirik berkepanjangan pada neonatus dengan BBLSR dengan hasil kultur darah negatif dan untuk membandingkan luaran antara kelompok subjek yang menerima antibiotik empirik kurang dari 2 minggu dan yang menerima antibiotik empirik selama lebih dari 2 minggu, di ruang NICU Rumah Sakit Pendidikan Dr. Soetomo, Surabaya. 


\section{Bahan dan Metode}

Studi ini merupakan studi retrospektif pada BBLSR dengan sepsis, yang dirawat di RSUD Dr. Soetomo antara Januari 2017 sampai dengan Desember 2017. RSUD Dr. Soetomo merupakan rumah sakit tipe A di Surabaya, bersinergi dengan Fakultas Kedokteran Universitas Airlangga sebagai pusat pendidikan dan pusat rujukan neonatologi tersier di wilayah Indonesia bagian Timur, dengan kapasitas 25 tempat tidur di NICU. Teknik pengambil sampel menggunakan consecutive sampling dengan kriteria inklusi adalah subjek dengan usia 0-28 hari, dengan berat lahir antara 1000 gram-1499 gram, pasien dengan kondisi masih hidup setelah lebih dari 14 hari penggunaan antibiotik, tidak dijumpai adanya pertumbuhan kuman pada hasil kultur darah (steril). Kriteria eksklusi adalah data rekam medik tidak lengkap atau data tindakan tidak sesuai prosedur, adanya pertumbuhan kuman pada hasil kultur darah, penggunaan antibiotik tidak sesuai pedoman penggunaan antibiotik Rumah Sakit Pendidikan Dr. Soetomo, pasien meninggal kurang dari sama dengan 14 hari penggunaan antibiotik, terdapat anomali kongenital ataupun kelainan kromosom. Penelitian ini telah mendapat persetujuan laik etik dari Komisi Etik Penelitian Kesehatan RSUD Dr. Soetomo Surabaya dengan nomor: 1302/KEPK/ VII/2018.

Data karakteristik demografi dan informasi relevan lainnya mengenai kondisi ibu maupun neonatus didokumentasikan dari data rekam medik pasien. Sepsis neonatus awitan lambat (SNAL) didiagnosis berdasarkan kriteria Centers for Disease Control and Prevention $(C D C)$, merupakan klinis curiga sepsis yang disertai dengan hasil kultur positif dari situs yang normalnya steril dan dijumpai pada sampel darah kultur dari neonatus usia lebih dari 3 hari. Klasifikasi sepsis meliputi possible: hanya ada manifestasi klinis, probable: manifestasi klinis ditambah skor hema- tologi positif, sel darah putih $<5.000 \mathrm{sel} / \mathrm{mm}^{3}$ atau $>20.000 \mathrm{sel} / \mathrm{mm}^{3}$, trombosit $<150.000 /$ $\mathrm{mm}^{3}$, kadar C-reactive protein $(C R P)>10$ $\mathrm{mg} / \mathrm{L}$, definite: tanda klinis ditambah kultur darah positif.,3,7 Enterokolitis nekrotikan (EKN) dinilai berdasarkan kriteria Bell. ${ }^{10-13}$

Semua subjek dengan diagnosis probable sepsis sesuai kriteria di atas, diberikan antibiotik empirik, berdasarkan data dari pola kuman dan resistensi antibiotik yang telah ditetapkan di RSUD Dr. Soetomo, yaitu lini pertama adalah amipisilin dan gentamisin, lini kedua adalah cefoperazone sulbactam dan amikasin, lini ketiga adalah meropenem. Setiap sebelum pemberian antibiotik, wajib untuk dilakukan pemeriksaan kultur darah terlebih dahulu sesuai standar prosedur operasional, yaitu mengambil darah $0,5 \mathrm{ml}$ yang kemudian disimpan dalam tabung kultur darah dan segera dikirim ke unit laboratorium. Pada bayi dengan hasil kultur darah tidak ditemukan pertumbuhan bakteri, keputusan untuk melanjutkan antibiotik atau tidak melanjutkan penggunaan antibiotik ditentukan oleh dokter penanggung jawab pasien berdasarkan pertimbangan dari temuan klinis sepsis seperti instabilitas suhu, letargi, takikardi, takipnu, intoleransi glukosa, juga intoleransi minum, yang ditunjang dengan pemeriksaan tambahan lain, yaitu adanya leukositosis atau leukopenia, trombositopenia, dan CRP.

Neonatus yang masuk dalam kriteria inklusi dikategorikan menjadi dua kelompok, yaitu kelompok I dan kelompok II berdasarkan atas durasi dari terapi antibiotik. Kelompok I adalah kelompok neonatus yang masuk kriteria inklusi yang menerima antibiotik selama kurang dari sama dengan 2 minggu dan kelompok II adalah kelompok neonatus yang masuk kriteria inklusi yang mendapatkan antibiotik selama lebih dari 2 minggu. Faktor risiko untuk terapi antibiotik yang berkepanjangan dan luaran akhir dibandingkan di antara kedua kelompok tersebut. 
Analisis faktor risiko dan luaran dari penggunaan antibiotik empirik dalam jangka panjang secara independent dilakukan dengan menggunakan analisis univariate, selanjutnya analisis regresi logistik multiple dari variabel-variabel yang ada dilakukan untuk variabel dengan hasil analisis univariate $p$ $<0,20$. Level signifikansi statistik dari hasil analisis regresi logistik adalah kurang dari 0,05 .

\section{Hasil}

Sebanyak 1.170 neonatus yang masuk ke dalam NICU selama periode studi (Januari 2017-Desember 2017), didapatkan 497 neonatus dengan berat badan lahir sangat ren- dah dengan 378 subjek didiagnosis sepsis. Sejumlah 87 neonatus memenuhi kriteria inklusi dan dimasukkan ke dalam analisis akhir.

Kelompok I terdiri dari 37 neonatus dengan terapi antibiotik kurang dari sama dengan 2 minggu dan kelompok II terdiri dari 50 neonatus dengan terapi antibiotik lebih dari 2 minggu. Jumlah neonatus dengan riwayat lahir dari ibu dengan penyakit infeksi pada kelompok I dan II sebanyak 4 orang $(30 \%)$ dan 9 orang $(70 \%)$. Rata-rata usia gestasi adalah kelompok I adalah $31,8 \pm 2,4$ minggu dan kelompok II adalah $29,8 \pm 2,5$ minggu dan rata-rata berat lahir adalah $1296,4 \pm 156,8$ gram dan $1157,9 \pm 231,4$ gram (Tabel 1).

Tabel 1. Analisis univariat antara karakteristik pasien dengan lama penggunaan antibiotik empirik.

\begin{tabular}{|c|c|c|c|}
\hline Karakteristik & Kelompok I (\%) $(\mathrm{n}=37)$ & Kelompok II (\%) $(n=50)$ & $p$ \\
\hline \multicolumn{4}{|l|}{ Jenis kelamin } \\
\hline Laki & $19(44)$ & $24(56)$ & 0,22 \\
\hline Perempuan & $18(41)$ & $26(59)$ & \\
\hline \multicolumn{4}{|l|}{ Berat lahir (gram) } \\
\hline 1000 & $1(6)$ & $16(94)$ & $<0,001$ \\
\hline $1001-1499$ & $36(51)$ & $34(59)$ & \\
\hline \multicolumn{4}{|l|}{ Usia kehamilan (minggu) } \\
\hline $28-32$ & $5(19)$ & $22(81)$ & 0,21 \\
\hline$>32$ & $32(53)$ & $28(47)$ & \\
\hline \multicolumn{4}{|l|}{ Cara persalinan } \\
\hline Spontan & $7(37)$ & $12(63)$ & 0,24 \\
\hline Sectio cesarea & $30(44)$ & $38(56)$ & \\
\hline \multicolumn{4}{|l|}{ Lokasi persalinan } \\
\hline RSUD Dr. Soetomo & $28(44)$ & $35(56)$ & 0,28 \\
\hline Lain-lain & $9(38)$ & $15(63)$ & \\
\hline \multicolumn{4}{|l|}{ Janin } \\
\hline Tunggal & $22(45)$ & $27(55)$ & 0,07 \\
\hline Multipel & $15(39)$ & $23(61)$ & \\
\hline $\begin{array}{l}\text { Ibu korioamnionitis atau ke- } \\
\text { tuban pecah dini }\end{array}$ & $4(31)$ & $9(69)$ & 0,11 \\
\hline Ibu penyakit maternal lain & $30(46)$ & $35(54)$ & 0,15 \\
\hline Terapi Pematangan paru & $23(44)$ & $29(56)$ & 0,27 \\
\hline Asfiksia & $8(40)$ & $12(60)$ & 0,49 \\
\hline
\end{tabular}

Keterangan: Kelompok 1 adalah neonatus dengan penggunaan terapi antibiotik empirik selama kurang dari sama dengan 2 minggu; Kelompok 2 adalah neonatus dengan penggunaan terapi antibiotik empirik selama lebih dari 2 minggu. 
Subjek dalam penelitian ini mendapatkan berbagai tindakan saat hasil kultur darah awal didapatkan steril, yaitu sejumlah $61 \%$ menggunakan non-invasive ventilation, 39\% dengan invasive ventilation, dan $23 \%$ riwayat penggunaan surfaktan (Tabel 2).

Analisis regresi logistik multiple menunjukkan asosiasi signifikan antara terapi antibiotik empirik yang berkepanjangan dengan berat badan lahir sangat rendah pada 1,000 gram $(\mathrm{OR}=0,02 ; 95 \% \mathrm{Cl}=0,001-0,16 ; \mathrm{p}<$ $0,001), N I V(O R=13,93 ; 95 \% \mathrm{Cl}=3,97-48,88$; $\mathrm{p}<0,001)$ dan invasive ventilation $(\mathrm{OR}=$ $67,65,95 \% \mathrm{Cl}=15,44-296,52, p<0,001)$. Selain itu, riwayat ibu dengan penyakit infeksi korioamnioitis atau ketuban pecah dini, ibu dengan penyakit penyerta lain dan kehamilan multipel memiliki relasi secara positif terhadap terapi antibiotik empirik berkepanjangan (Tabel 3).
Pada kelompok II yaitu dengan penggunaan antibiotik lebih dari 2 minggu memperlihatkan luaran pada subjek dengan SNAL lebih tinggi, baik dalam jumlah kejadian maupun sebagai penyebab kematian yang bermakna $(p<0,001)$. Selain itu, pada kelompok ini dijumpai angka kejadian EKN yang lebih tinggi daripada kelompok I yaitu sebanyak $9(60 \%)$ neonatus dan sebagai penyebab kematian yang bermakna ( $p=$ 0,002) (Tabel 4). Rerata durasi terapi antibiotik pada kelompok I dan kelompok II adalah $9,2 \pm 2,5$ dan $17,9 \pm 3,2$ hari, dengan lama rawat adalah $19,7 \pm 8,5$ dan $27,2 \pm 13,1$ hari. Melalui hasil analisis statistik menunjukkan jika adanya asosiasi positif antara durasi penggunaan terapi antibiotik dengan lama rawat yang panjang di rumah sakit (koefisien korelasi Pearson $=0,75 ; p<0,001)$.

Tabel 2. Analisis univariat antara jenis tindakan dengan lama penggunaan antibiotik empirik.

\begin{tabular}{lccc}
\hline \multicolumn{1}{c}{ Tindakan } & Kelompok I $(\%)(n=37)$ & Kelompok II $(\%)(n=50)$ & $p$ \\
\hline NIV & $11(21)$ & $42(79)$ & $<0,001$ \\
Surfaktan & $5(25)$ & $15(75)$ & 0,24 \\
Invasive Ventilation & $4(12)$ & $30(88)$ & $<0,001$ \\
\hline
\end{tabular}

Keterangan: Kelompok 1 adalah neonatus dengan penggunaan terapi antibiotik empirik selama kurang dari sama dengan 2 minggu; Kelompok 2 adalah neonatus dengan penggunaan terapi antibiotik empirik selama lebih dari 2 minggu.

Tabel 3. Analisis faktor risiko terhadap terapi antibiotik empirik jangka panjang (regresi logistik multipel).

\begin{tabular}{lccc}
\hline \multicolumn{1}{c}{ Faktor risiko } & OR & $95 \% \mathrm{Cl}$ & $\mathrm{p}$ \\
\hline $\begin{array}{l}\text { Berat lahir (gram) } \\
\quad \text { 1000 }\end{array}$ & 0,02 & $0,001-0,16$ & $<0,001^{*}$ \\
$\begin{array}{l}\text { Janin } \\
\quad \text { Tunggal }\end{array}$ & 0,16 & $0,03-0,82$ & $0,03^{*}$ \\
$\begin{array}{l}\text { Ibu korioamnionitis atau } \\
\text { ketuban pecah dini }\end{array}$ & 0,15 & $0,05-0,52$ & $0,003^{*}$ \\
Ibu penyakit maternal lain & 5,72 & $1,02-32,15$ & $0,004^{*}$ \\
NIV & 13,93 & $3,97-48,88$ & $<0,001^{*}$ \\
Invasive Ventilation & 67,65 & $15,44-296,52$ & $<0,001^{*}$ \\
\hline
\end{tabular}

*signifikan: $p<0,05$ 
Tabel 4. Analisis univariat luaran subjek penelitian terhadap lama penggunaan antibiotik.

\begin{tabular}{lccc}
\hline \multicolumn{1}{c}{ Luaran } & Kelompok I $(\%)(\mathrm{n}=37)$ & Kelompok II $(\%)(\mathrm{n}=50)$ & $\mathrm{p}$ \\
\hline EKN & $6(40)$ & $9(60)$ & 0,39 \\
SNAL & $9(22)$ & $32(78)$ & $<0,001^{*}$ \\
$\begin{array}{l}\text { Penyebab kematian } \\
\text { setelah usia 14 hari }\end{array}$ & & & \\
$\quad$ EKN & $1(34)$ & & \\
$\quad$ SNAL & $1(12)$ & $2(66)$ & $0,002^{*}$ \\
\hline
\end{tabular}

Keterangan: Kelompok 1 adalah neonatus dengan penggunaan terapi antibiotik empirik selama kurang dari sama dengan 2 minggu; Kelompok 2 adalah neonatus dengan penggunaan terapi antibiotik empirik selama lebih dari 2 minggu. ${ }^{*}$ signifikan: $p<$

\section{Pembahasan}

Sepsis neonatus menyebabkan peningkatan dari mortalitas bayi. ${ }^{14} \mathrm{Di}$ negara berkembang seperti Indonesia, jumlah bayi dengan sepsis dapat mencapai 3.000 .000 bayi setiap tahunnya. Studi mengenai neonatus di seluruh dunia menunjukkan bahwa $94 \%$ dari laporan mengenai mortalitas berasal dari negara-negara berkembang dan $25 \%$ dari kematian neonatus terjadi karena sepsis dengan hasil kultur yang steril serta dengan besaran biaya perawatan dalam penggunaan antibiotik mampu mencapai puluhan juta rupiah setiap pasiennya. ${ }^{14-16}$ Angka ini menekankan tentang besarnya penggunaan terapi antibiotik secara dini pada neonatus, pada kelompok berat lahir sangat rendah memang sangat dipertimbangkan karena kerentanannya terhadap infeksi yang serius disebabkan oleh sistem imun yang imatur dan berbagai prosedur invasif yang dilakukan. ${ }^{17,18}$ Walaupun demikian, bila hasil kultur negatif dan bayi secara klinis asimptomatik, maka direkomendasikan untuk menghentikan antibiotik setelah 3-7 hari, dan bayi seharusnya tidak diberikan antibiotik yang berkepanjangan. ${ }^{19}$ Rekomendasi ini telah banyak dijadikan dasar pelayanan NICU di beberapa pusat pelayanan, namun yang menjadi perbedaan adalah bagaimana seorang dokter penanggung jawab pasien (DPJP) dalam me- mastikan kondisi klinis dari neonatus BBLSR tersebut apakah masih dalam kondisi infeksi ataupun telah bebas dari infeksi disaat hasil kultur darah negatif, sehingga subjektifitas sangat tinggi dalam hal ini. Centers for Disease Control and Prevention (CDC) menjelaskan klasifikasi sepsis meliputi possible: hanya ada manifestasi klinis, probable: manifestasi klinis ditambah skor hematologi positif; sel darah putih $<5.000 \mathrm{sel} / \mathrm{mm}^{3}$ atau $>20.000 \mathrm{sel} /$ $\mathrm{mm}^{3}$, trombosit $<150.000 / \mathrm{mm}^{3}$, kadar $C$ reactive protein $(C R P)>10 \mathrm{mg} / \mathrm{L}$, dan definite: tanda klinis ditambah kultur darah positif. 3,7

Fakta menunjukkan bahwa beberapa pusat perawatan neonatus masih memberikan terapi antibiotik empirik dalam periode yang panjang dengan golongan antibiotik yang silih berganti, baik mulai dari lini pertama, kedua maupun sampai ketiga sesuai dengan pola kuman dan resistensi antibiotik di rumah sakit masing-masing yang telah ditentukan.17,20 Alasan yang diberikan untuk pemberian antibiotik di antaranya adalah bayi lahir prematur, perawatan di NICU, pemasangan jalur intravena, kesulitan dalam diagnosis definite sepsis, angka kultur negatif yang tinggi walaupun manifestasi klinis positif, hasil abnormal pada kriteria hematologi $C D C$, diagnosis dengan dasar manifestasi klinis yang nyata, dan adanya faktor risiko untuk infeksi sistemik seperti berat badan, penggunaan ventilasi mekanik, dan lain-lain. 
Walaupun seharusnya pasien dengan faktor risiko tersebut tidak perlu mendapat terapi antibiotik apabila secara klinis tidak ditemukan gejala dan tanda infeksi serta pemeriksaan penunjang lain tidak mendukung. . $^{21-24}$

Studi ini juga mendapatkan sejumlah $23 \%$ bayi berat lahir sangat rendah dengan diagnosis sepsis memiliki kultur darah yang steril, dan penggunaan antibiotik tetap dilanjutkan dengan berbagai macam pertimbangan faktor-faktor risiko tertinggi yang ada yaitu berat badan lahir sangat rendah, penggunaan invasive ventilation maupun noninvasive ventilation (NIV). Berdasarkan kondisi ini, terlihat jika pada penggunaan lama alat bantu napas terutama invasive ventilation seringkali mengakibatkan pasien mengalami VAP, sehingga terapi antibiotik menjadi panjang dan mengakibatkan luaran yang buruk. Pada studi ini bisa disimpulkan bahwa menghindari invasive ventilation sangat disarankan kecuali benar-benar diperlukan. Namun pada penggunaan NIV dijumpai juga sebagai penyebab yang signifikan yang dapat diperkirakan, selain karena peyebab prematuritas lainnya, Program Pencegahan Infeksi (PPI) merupakan salah satu pilihan sebagai upaya mengontrol penyebaran infeksi. ${ }^{11}$

Cotton et al melaporkan bahwa $65 \%$ dari beberapa pusat perawatan neonatus, antibiotik empirik diberikan selama lebih dari 5-36 hari bagi neonatus dengan kultur darah yang steril. ${ }^{6}$ Stark et al juga menyimpulkan dalam studinya jika durasi terapi antibiotik pada suatu rumah sakit dijumpai dua kali lipat lebih lama dibandingkan rumah sakit lainnya. ${ }^{17}$ Tantangan utama bukan dalam memulai antibiotik, namun memastikan dilanjutkannya antibiotik tanpa alasan yang kuat. ${ }^{20}$

Studi ini menghasilkan data yaitu rerata durasi terapi antibiotik pada kelompok I dan kelompok II adalah 9,2 $\pm 2,5$ dan 17,9 $\pm 3,2$ hari, yang terbukti terlihat memiliki dengan lama rawat yang lebih pada kelompok penggunaan antibiotik lebih dari 2 minggu yaitu adalah $27,2 \pm 13,1$ hari daripada $19,7 \pm 8,5$, dengan berkorelasi positif dalam analisisnya. Pada studi yang berbeda, faktor risiko yang dinyatakan untuk kelanjutan antibiotik empirik dikategorikan menjadi dua kelompok perinatal (komplikasi maternal, terutama ketuban pecah dini, kehamilan multipel, dan persalinan dengan operasi Caesar dan neonatal (berat lahir sangat rendah dan usia gestasi). ${ }^{15-19}$ Pada studi ini penyakit maternal, kehamilan multipel dan korioamnionitis atau ketuban pecah dini, berat lahir sangat rendah terutama 1000 gram merupakan faktor risiko yang signifikan dalam penggunaan antibiotik empirik berkelanjutan maupun perubahan antibiotik empirik sesuai tingkatan lini secara berulang. 1-3,20

Sebuah penelitian menunjukkan prevalensi dari sepsis awitan lambat pada neonatus dengan berat lahir sangat rendah prevalensinya di negara maju adalah 20\% dan Stoll et al. mendapatkan angka prevalensi $21 \% .9,21$ Lain halnya dengan penelitian Vain et al yang melaporkan pada negara berkembang lebih banyak dibandingkan pada negara industrial. ${ }^{22}$ Jadi, prevalensi $47 \%$ pada studi ini memerlukan telaah masalah segera dari program pencegahan infeksi untuk mengurangi angka infeksi yang didapat di rumah sakit.

Pada studi ini, mortalitas yang lebih tinggi setelah usia 14 hari terlihat pada kelompok II, yang mungkin disebabkan oleh beragam faktor risiko termasuk penyakit sebelumnya, infeksi sistemik atau dari komplikasi terapi antibiotik empirik yang berkepanjangan. Dari studi yang dilakukan oleh Cotten et al. dan Abdel Ghany et al. terapi antibiotik yang berkepanjangan berhubungan dengan meningkatnya angka mortalitas. Lebih lanjut, Hornik et al. melaporkan angka mortalitas dua kali lebih tinggi pada kelompok neonatus dengan SNAL. 6,23 
Pembuatan keputusan yang rasional untuk melanjutkan dan menghentikan antibiotik sangat penting. Serta perlu adanya tes diagnositik seperti kultur darah, hitung jumlah leukosit, penanda permukaan sel leukosit dan parameter infeksi tertentu seperti IT Ratio, $C R P$, procalcitonin untuk membantu mendiagnosis keberadaan atau ketiadaan infeksi sistemik. ${ }^{24}$ Sementara itu, saat ini banyak informasi bisa didapatkan dengan menjalankan Program Pencegahan Resistensi Antibiotik (PPRA) yang efektif. 25

\section{Kesimpulan}

Studi ini mendapatkan bahwa terapi antibiotik empirik yang berkepanjangan meningkatkan prevalensi dari SNAL, EKN, lama rawat, dan mortalitas pada neonatus dengan berat badan lahir sangat rendah, sehingga direkomendasikan untuk menghentikan antibiotik empirik secepat mungkin untuk meningkatkan efisiensi dalam perawatan pasien. $\mathrm{Na}-$ mun, keputusan mengenai durasi yang optimal dari antibiotik empirik hanya dapat dibuat ketika berbagai masalah dalam mendiagnosis dan mengobati infeksi neonatus telah diselesaikan. Keterbatasan pada studi ini adalah retrospektif, kecilnya jumlah sampel yang didapatkan serta terbatasnya informasi biaya perawatan pasien. Hasil penelitian ini diharapkan mampu memberikan sedikit gambaran perihal usaha dalam merawat pasien neonatus dengan berat lahir rendah di era JKN.

\section{Daftar Pustaka}

1. Clark RH, Bloom BT, Spitzer AR, Gerstmann DR. Reported Medication Use in the Neonatal Intensive Care Unit: Data from a Large National Data Set. Pediatrics. 2006; 117(6):1979-87. doi: 10.1542/peds.20051707. [PubMed: 16740839].
2. Cantey JB, Sanchez PJ. Prolonged Antibiotic Therapy for "Culture- Negative" Sepsis in Preterm Infants: It's Time to Stop!. J Pediatr. 2011; 159(5):707-8. doi: $\underline{10.1016 /}$ j.jpeds.2011.07.032. [PubMed:21885065].

3. Kuppala VS, Meinzen-Derr J, Morrow AL, Schibler KR. Prolonged Initial Empirical Antibiotic Treatment is Associated with Adverse Outcomes in Premature Infants. $J$ Pediatr. 2011; 159(5):720-5. doi: $\underline{10.1016 /}$ j.jpeds.2011.05.033. [PubMed: 21784435].

4. Tripathi N, Cotten CM, Smith PB. Antibiotic Use and Misuse in the Neonatal Intensive Care Unit. Clin Perinatol. 2012;39(1):61-8. doi: 10.1016/i.clp.2011.12.003. [PubMed: 22341537].

5. Piantino JH, Schreiber MD, Alexander K, Hageman J. Culture Negative Sepsis and Systemic Inflammatory Response Syndrome in Neonates. Neo Rev. 2013;14 (6):e294-305. doi: 10.1542/neo.14-6-e294.

6. Cotten CM, Taylor S, Stoll B, Goldberg RN, Hansen NI, Sanchez PJ, et al. Prolonged Duration of Initial Empirical Antibiotic Treatment is Associated with Increased Rates of Necrotizing Enterocolitis and Death for Extremely Low Birth Weight Infants. Pediatrics. 2009; 123(1):58-66. doi: 10.1542/peds.2007-3423. [PubMed: 19117861].

7. Falciglia G, Hageman JR, Schreiber M, Alexander K. Antibiotic Therapy and Early Onset Sepsis. Neo Rev. 2012; 13(2):e8693. doi: 10.1542/neo.13-2-e86.

8. Stoll BJ, Hansen NI, Higgins RD, Fanaroff AA, Duara S, Goldberg R, et al. Very Low Birth Weight Preterm Infants with Early Onset Neonatal Sepsis: the Predominance of Gram-Negative Infections Continues in the National Institute of Child Health and Human Development Neonatal Research Network, 2002-2003. Pediatr Infect Dis J. 2005; 24(7):635-9. [PubMed: 15999007]. 
9. Stoll BJ, Hansen N, Fanaroff AA, Wright LL, Carlo WA, Ehrenkranz RA, et al. LateOnset Sepsis in very Low Birth Weight Neonates: the Experience of the NICHD Neonatal Research Network. Pediatrics. 2002; 110(2 Pt 1):285-91. [PubMed: $12165580]$.

10. Bell MJ, Ternberg JL, Feigin RD, Keating JP, Marshall R, Barton L, et al. Neonatal Necrotizing Enterocolitis. Therapeutic Decisions based upon Clinical Staging. Ann Surg. 1978; 187(1):1-7. [PubMed: 413500].

11. Papile LA, Burstein J, Burstein R, Koffler $\mathrm{H}$. Incidence and Evolution of Subependymal and Intraventricular Hemorrhage: a Study of Infants with Birth Weights Less Than 1,500 gm. J Pediatr. 1978; 92 (4):529-34. [PubMed: 305471].

12. An international classification of retinopathy of prematurity. The Committee for the Classification of Retinopathy of Prematurity. Arch Ophthalmol. 1984;102(8):1130 -4. [PubMed: 6547831].

13. Wirtschafter DD, Padilla $G$, Suh $O$, Wan K, Trupp D, Fayard EE. Antibiotic Use for Presumed Neonatally Acquired Infections Far Exceeds that for Central LineAssociated Blood Stream Infections: an Exploratory Critique. J Perinatol. 2011; 31 (8):514-8. doi: 10.1038/jp.2011.39. [PubMed:21546938].

14. Smith PB, Benjamin DK. Choosing the Right Empirical Antibiotics for Neonates. Arch Dis Child Fetal Neonatal Ed. 2011; 96(1):F2-3. doi: $\underline{10.1136 /}$ adc.2010.188938. [PubMed: 20547581].

15. Stoll BJ, Hansen NI, Sanchez PJ, Faix RG, Poindexter BB, Van Meurs KP, et al. Early Onset Neonatal Sepsis: the Burden of Group B Streptococcal and E. coli Disease Continues. Pediatrics. 2011; 127 (5):817-26. doi: 10.1542/peds.20102217. [PubMed: 21518717].
16. Sivanandan S, Soraisham AS, Swarnam K. Choice and Duration of Antimicrobial Therapy for Neonatal Sepsis and Meningitis. Int J Pediatr. 2011; 2011:712150. doi: $10.1155 / 2011 / 712150$. [PubMed: 22164179.

17. Alexander VN, Northrup V, Bizzarro MJ. Antibiotic Exposure in the Newborn Intensive Care Unit and the Risk of Necrotizing Enterocolitis. J Pediatr. 2011; 159(3):392 -7. doi: 10.1016/j.jpeds.2011.02.035. [PubMed: 21489560].

18. Cotten CM, Smith PB. Duration of Empirical Antibiotic Therapy for Infants Suspected of Early-Onset Sepsis. Curr Opin Pediatr. 2013; 25(2):167- 71. doi: $\underline{10.1097 /}$ MOP.0b013e32835e01f6. [PubMed: 23407181.

19. Russell AB, Sharland M, Heath PT. Improving Antibiotic Prescribing in Neonatal Units: Time to Act. Arch Dis Child Fetal Neonatal Ed. 2012; 97(2):F141-6. doi: 10.1136/adc.2007.120709. [PubMed: 21037285.

20. Patel SJ, Oshodi A, Prasad P, Delamora $P$, Larson $E$, Zaoutis $T$, et al. Antibiotic Use in Neonatal Intensive Care Units and Adherence with Centers for Disease Control and Prevention 12 Step Campaign to Prevent Antimicrobial Resistance. Pediatr Infect Dis J. 2009; 28(12):1047-51. doi: 10.1097/INF.0b013e3181b12484. [PubMed: 19858773].

21. Polin RA, Denson $S$, Brady MT, Papile LA, Baley JE, Carlo WA, et al. Strategies for Prevention of Health Care-Associated Infections in the NICU. Pediatrics. 2012; 129(4):e1085-93. doi: 10.1542/peds.2012 -0145. [PubMed: 22451712].

22. Polin RA, Papile LA, Baley JE, Bhutani VK, Carlo WA, Cummings J, et al. Management of Neonates with Suspected or Proven Early-Onset Bacterial Sepsis. Pediatrics. 2012; 129(5):1006-15. doi: 
23. Yang YN, Tseng HI, Yang SN, Lu CC, Chen HL, Chen CJ. A Strategy for Reduction of Antibiotic Use in New Patients Admitted to a Neonatal Intensive Care Unit. Pediatr Neonatol. 2012; 53(4):24551. doi: 10.1016/i.pedneo.2012.06.009. [PubMed: 22964282].

24. Stoll BJ, Hansen NI, Bell EF, Shankaran S, Laptook AR, Walsh MC, et al. Neonatal Outcomes of Extremely Preterm Infants from the NICHD Neonatal Re- search Network. Pediatrics. 2010; 126 (3):443-56. doi: 10.1542/peds.20092959. [PubMed: 20732945].

25. Abdel Ghany EA, Ali AA. Empirical Antibiotic Treatment and the Risk of $\mathrm{Ne}$ crotizing Enterocolitis and Death in Very Low Birth Weight Neonates. Ann Saudi Med. 2012; 32(5):521-6. doi: 10.5144/0256- 4947.2012.521. [PubMed: 22871623]. 